\title{
GM1-Binding Conjugates to Improve Intestinal Permeability
}

\author{
Alexandre Melkoumov ${ }^{\dagger}$, Isabelle St-Jean ${ }^{\dagger}$, Xavier Banquy ${ }^{\dagger}$, Grégoire Leclair ${ }^{\dagger *}$ and Jeanne Leblond \\ Chain $^{\dagger *}$ \\ ${ }^{\dagger}$ Faculty of Pharmacy, Université de Montréal, H3C 3J7, Montréal, Québec, Canada \\ *Co-corresponding authors. Tel : +1-514-343-6111 ext 0361 ; Fax : +1-514-343-2102 ; E-mail : \\ Jeanne.leblond-chain@umontreal.ca; gregoire.leclair@umontreal.ca
}


Table of contents graphic (TOC)

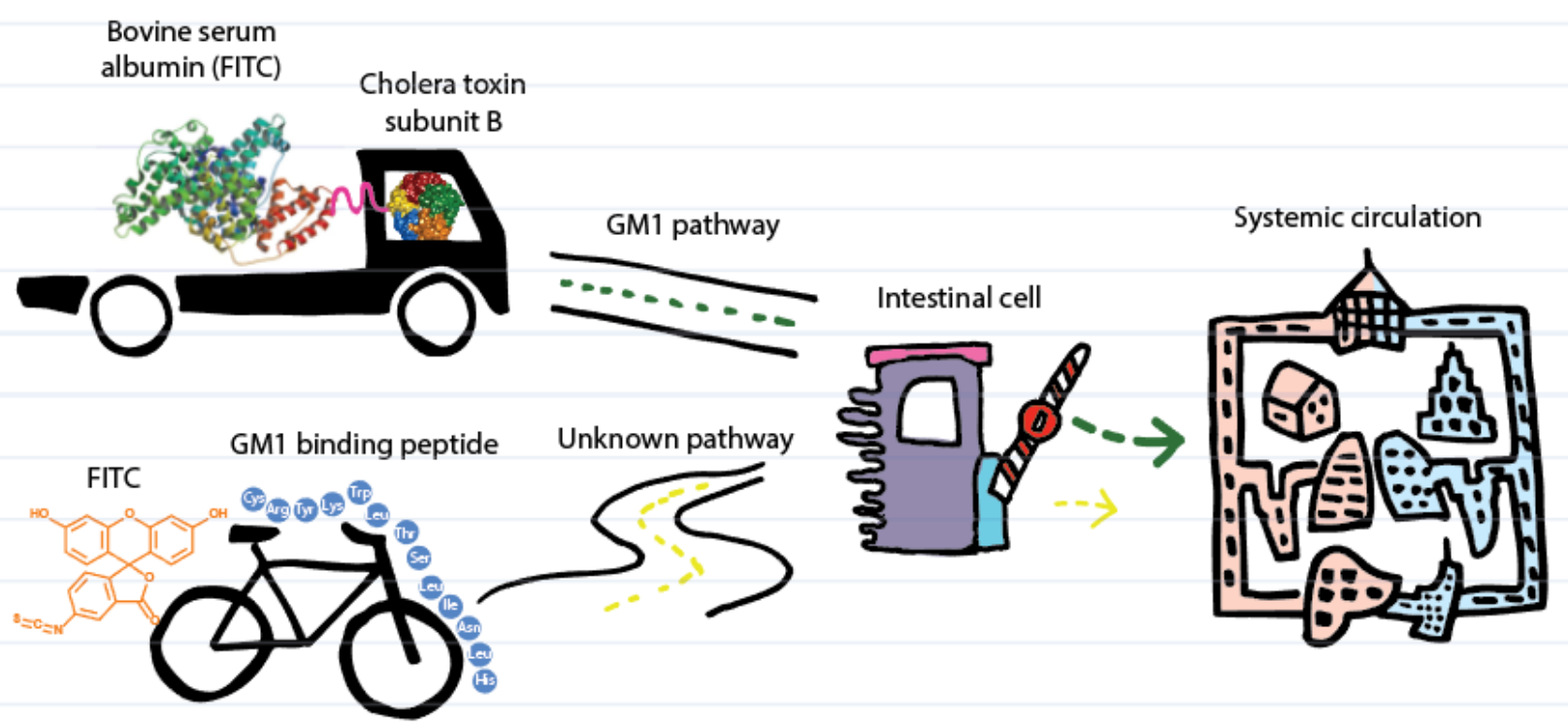




\begin{abstract}
Drugs and proteins with poor intestinal permeability have a limited oral bioavailability. To remediate this problem, a receptor-mediated endocytosis and transcytosis approach was explored. Indeed, the non-toxic $\beta$ subunit of cholera toxin (CTB) can cross the intestinal barrier by binding to receptor GM1. In this study, we explored the use of GM1-binding peptides and CTB as potential covalent carriers of poorly permeable molecules. GM1-binding peptides (G23, P3) and CTB were conjugated to poorly permeable fluorescent probes such as FITC and albumin-FITC using triethylene glycol spacers and click chemistry. The affinity of the peptide conjugates with receptor GM1 was confirmed by isothermal titration calorimetry or microscale thermophoresis and the results suggested the involvement of non-specific interactions. Conjugating the model drugs to G23 and P3 improved the internalization into Caco-2 and T84 cells, although the process was not dependent of the amount of GM1 receptor. However, conjugation of BSA-FITC to CTB increased the internalization in the same cells in a GM1-dependent pathway. Peptides conjugates demonstrated a limited permeability through a Caco-2 monolayer, whereas G23- and CTB-conjugates slightly enhanced permeability through a T84 cell monolayer compared to model drugs alone. Since CTB can improve the permeability of large macromolecules such as albumin, it is an interesting carrier for the improvement of oral bioavailability of various other macromolecules such as heparins, proteins and siRNAs.
\end{abstract}




\section{Abbreviations:}

BBB: Blood-Brain-Barrier

Boc: tert-butyloxycarbonyl protecting group

$\mathrm{Boc}_{2} \mathrm{O}$ : Di-tert-butyl dicarbonate

CT: Cholera toxin

CTB: Cholera toxin subunit $B$

Cy5-NHS: Cyanine 5 monosuccinimidyl ester

DBCO: Dibenzocyclooctyne

DCM: Dichloromethane

DMF : N,N-Dimethylformamide

$E t_{3} N$ : Triethylamine

EtOAc: Ethyl acetate

FITC: Fluorescein isothiocyanate

GM1: Monosialotetrahexosylganglioside

GMBS: $N$ - $\gamma$-maleimidobutyryl-oxysuccinimide ester

HBSS: Hank's balanced salt solution

ITC: Isothermal titration calorimetry

MBCD: Methyl-beta-cyclodextrin

MST: Microscale thermophoresis

NHS: N-Hydroxysuccinimide

$P_{a p p}:$ Apparent permeability coefficient

PBS: Phosphate buffer saline

PPMP: DL-threo-1-phenyl-2-palmitoylamino-3-morpholino-1-propanol

RT: Room temperature

SPR: Surface plasmon resonance

TBS: Tris-buffered saline

TFA: Trifluoroacetic acid 


\section{Introduction}

Recent advances in biologic therapies such as fusion proteins, monoclonal antibodies and therapeutic peptides have demonstrated their efficacy and safety for the treatment of multiple diseases. $(I)$ Unfortunately, oral bioavailability of biomacromolecules is still a major frontier in drug delivery.(2) Interestingly, two peptide drugs — desmopressin $(1069 \mathrm{~g} / \mathrm{mol})$ and sirolimus $(914 \mathrm{~g} / \mathrm{mol})$ - are commercially available as an oral solution and tablet, respectively. However, their oral bioavailability remains low and variable: $0.08 \%$ to $0.16 \%$ for desmopressin,(3) 15 to $20 \%$ for sirolimus.(4) Macromolecules exhibiting higher molecular weight (>1100 g/mol), such as insulin, are mainly administered by injection, which is often associated with pain, swelling and infection at injection site. These adverse effects decrease patient compliance and can delay the initiation of an intravenous therapy, resulting in diminished clinical efficacy and life expectancy.(5-7) Oral formulation of insulin remains the Holy Grail in the pharmaceutic field and continues to face the difficulty of highly variable absorption.(8)

Biomacromolecules have poor oral bioavailability due to the multiple barriers encountered in the gastrointestinal tract such as: (i) an enzymatic and acidic barrier, (ii) a physical mucus barrier and (iii) a cellular permeability barrier.(9) Multiple strategies have been developed to address each of these issues respectively: (i) enzyme inhibitors and enteric coatings to overcome digestion, (ii) nanoparticulate systems able to cross the mucus layer, and (iii) permeation enhancers and receptor-mediated conjugates to facilitate intestinal permeability.(10) Although nanoparticles have demonstrated interesting results, no formulation has been commercialized to this date.(9) Permeation enhancers usually target the tight junctions between enterocytes, which they open transiently, allowing paracellular and/or transcellular absorption of macromolecules. $(10,11)$ These systems have progressed into clinics, as a glucagon-like peptide-1 receptor agonist (GLP-1, $4114 \mathrm{~g} / \mathrm{mol})$ administered with the permeation enhancer N-[8-(2hydroxybenzoyl) amino] caprylate (SNAC) completed phase III clinical trials. (12) The toxicity in a chronic administration regimen needs to be carefully examined, due to possible absorption of bystander pathogens and toxins.(11) 
Interestingly, some natural compounds, such as the toxins from the $\mathrm{AB}_{5}$ family, are able to target enterocytes and cross multiple barriers through an endocytosis pathway.(13) Among them, Cholera toxin (CT) is secreted by the bacteria Vibrio cholerae. It is composed of two subunits exhibiting specific roles: the subunit B (CTB) is a non-toxic pentameric protein which binds to gangliosides GM1 (monosialotetrahexosylganglioside) or GT1b (trisialoganglioside) in intestinal cells. This binding crosslinks five GM1 molecules in the plasma membrane and triggers the internalization of the whole toxin (A and B) thanks to the cholesterol islets and the lipid rafts associated proteins.(14) CT reaches the endoplasmic reticulum via a specific retrograde pathway and the subunit $\mathrm{A}$ is then dissociated from the subunit B to exert its toxic effect.(14-16) Interestingly, transcytosis of cholera toxin subunit B (CTB) was observed by Lencer et al. since 1995 in polarized cell lines, such as T84.(17, 18) Since then, CTB has been used to prepare fusion proteins with GFP (19), insulin (20), myelin binding protein (21) and amyloid- $\beta$ peptide,(22) and has enabled the oral administration of therapeutic proteins or peptides. However, conjugating CTB to a gold nanoparticle did not induce transcytosis through enterocytes, due to the presence of cell glycocalyx in the mucus of enterocytes.(23) Nevertheless, CTB-decorated small liposomes $(<100 \mathrm{~nm}$ in diameter $)$ were able to generate a sufficient mucosal immunoglobulin A level to prevent from infectious diseases, probably processing through the M cells.(24) We therefore hypothesized that designing a conjugate of poorly permeable drugs to a GM1-binding unit could improve their intestinal permeability and consequently their bioavailability.

Although CTB has proven to be efficient at improving the bioavailability of macromolecules, it remains an expensive and relatively complex solution to improve oral permeability. Therefore, we first investigated synthetic peptides reported to bind to gangliosides, such as P3 (25) and G23,(26) identified by phage display. The latter, also abbreviated Tet 1 due to tetanus toxin-like binding characteristics, is a 13-mer peptide which exhibits neuron targeting properties. $(27,28)$ Initially identified to bind GT1b, Georgieva et al. demonstrated that G23 also binds to GM1.(29) This group grafted the peptide on the surface of polymersomes and demonstrated the transcytosis of the targeted complexes through the Blood- 
Brain Barrier (BBB) in vitro and in vivo, after intravenous administration in mice.(30) Supporting this idea, G23 was coated on an alginate/doxorubicin/iron nanoparticle and significantly improved transcytosis on an in vitro BBB model, as well as brain accumulation, after intravenous injection in mice.(31)

Taken into consideration all these data, we hypothesized that the conjugation of a poorly permeable molecule to a GM1-binding peptide (G23, P3) would improve the uptake and transcytosis of model drugs across an in vitro model of the intestinal barrier. The conjugates were synthesized using short polyethylene glycol spacers to favor ligand display. Since conjugation can modify the affinity of the GM1-binding peptides, affinity of the conjugates for the GM1 receptor was evaluated using isothermal titration calorimetry (ITC) or microscale thermophoresis (MST). In parallel, we hypothesized that click chemistry could be used instead of recombinant protein production to prepare CTB-conjugates of macromolecules, while still improving their permeability through an in vitro model of the intestinal barrier. Cellular uptake of the peptide and protein conjugates was evaluated in intestinal Caco-2 and T84 cells, the latter previously used for CTB transcytosis. $(17,18)$ The permeability of the conjugates was evaluated through a monolayer of the same differentiated intestinal cells. 


\section{Experimental section}

\section{Materials}

GM1 was purchased from Santa Cruz Biotechnology (Dallas, TX, USA), Cholera toxin subunit B, BSAFITC and all other chemicals were purchased from Sigma-Aldrich (Oakville, ON, Canada). Peptide G23 (HLNILSTLWKYRC), Peptide P3 (VWRLLAPPFSNRLLPC) and a scrambled version of G23 (KISHLLNYRTWL), were custom synthesized by Biomatik (Cambridge, ON, Canada). All solvents, buffers and culture media were purchased from Thermo Fischer Scientific (Pittsburgh, PA, USA) and were of analytical grade and were used as received. Genistein and chlorpromazine were obtained from Sigma-Aldrich (Oakville, ON, Canada), 5-(N-Ethyl-N-isopropyl)-Amiloride (EIPA) was obtained from Santa Cruz Biotechnology (Dallas, TX, USA), Pitstop $2^{\mathrm{TM}}$ was obtained from Abcam ${ }^{\circledR}$ (Toronto, ON, Canada). All other chemicals were obtained from Sigma Aldrich (Oakville, ON, Canada) Alfa Aesar (Ward Hill, MA, USA) and Oakwood Chemical (West Columbia, SC, USA) and used as received. Caco-2 and T84 cells were purchased from ATCC (Manassas, VA, USA). Analytical and preparative LC/MS was performed on an Agilent 1260 Infinity system equipped with a single quadrupole Agilent 6120 mass spectrometer (Agilent Technologies, Mississauga, ON, Canada). ${ }^{1} \mathrm{H}$ and ${ }^{13} \mathrm{C}$ NMR were recorded on a Varian 400 WB spectrometer, using residual solvent peak for calibration. HRMS analyses were performed on a Waters Xevo G2-S QTOF.

\section{Synthesis of peptide conjugates}

Synthesis of 2 (32)

To a solution of $\mathrm{NH}_{2}-\mathrm{PEG}_{3}-\mathrm{NH}_{2}(872.2 \mathrm{mg}, 4.54 \mathrm{mmol})$ in dichloromethane (DCM, $\left.20 \mathrm{~mL}\right)$ was added dropwise a solution of $\mathrm{Boc}_{2} \mathrm{O}$ (148.2 mg, $0.68 \mathrm{mmol}, 0.15$ eq.) in $25 \mathrm{~mL}$ of DCM. Reaction was stirred for 5 hours at $4^{\circ} \mathrm{C}$ and then for 18 hours at room temperature. The organic phase was washed with water, dried with $\mathrm{MgSO}_{4}$, filtered off and concentrated under reduced pressure to afford a clear oil (134.3 mg, 67 \%): ${ }^{1} \mathrm{H}$ NMR (400 MHz, $\left.\mathrm{CDCl}_{3}\right) \delta(\mathrm{ppm}) 1.43(\mathrm{~s}, 9 \mathrm{H}), 1.96\left(\mathrm{br}, 2 \mathrm{H}, \mathrm{NH}_{2}\right), 2.88\left(\mathrm{~m}, 2 \mathrm{H}, \mathrm{CH}_{2}-\mathrm{NBoc}\right), 3.30$ $\left(\mathrm{m}, 2 \mathrm{H}, \mathrm{CH}_{2} \mathrm{NH}_{2}\right), 3.50-3.65\left(\mathrm{~m}, 12 \mathrm{H}, \mathrm{CH}_{2} \mathrm{O}\right) ;{ }^{13} \mathrm{C} \mathrm{NMR}\left(100 \mathrm{MHz}, \mathrm{CDCl}_{3}\right) \delta(\mathrm{ppm}) 28.41,40.36,41.64$, 
70.21, 70.50, 70.54, 73.17, 76.69, 156.06. LC-MS: RT = $1.141 \min (\lambda=220 \mathrm{~nm}),[\mathrm{M}+\mathrm{H}]^{+}=293.2$ calculated exact mass: 292.20.

Synthesis of $\mathbf{3}$

To a $1 \mathrm{~mL}$ DCM solution of compound $2(100.0 \mathrm{mg}, 342 \mu \mathrm{mol})$ was added N-methylmorpholine $(50 \mu \mathrm{L}$, 1.3 eq.) and GMBS (79.5 mg, 0.8 eq.). Reaction mixture was stirred overnight at room temperature. Mixture was then diluted in DCM (1 mL) and washed with a $5 \%$ citric acid solution $(2 \mathrm{~mL})$. The aqueous layer was further extracted with DCM $(3 \times 2 \mathrm{~mL})$. The combined organic layers were then dried with $\mathrm{MgSO}_{4}$, filtered off and concentrated under reduced pressure to afford a clear oil. The oil was further purified using a silica plug with ethyl acetate as eluent. (116.3 mg, $88 \%):{ }^{1} \mathrm{H} \mathrm{NMR}\left(400 \mathrm{MHz}, \mathrm{CDCl}_{3}\right) \delta$ (ppm) $6.65(\mathrm{~s}, 2 \mathrm{H}) 3.60-3.49\left(\mathrm{~m}, 14 \mathrm{H}, \mathrm{CH}_{2} \mathrm{O}\right) 3.39\left(\mathrm{t}, J=5.1 \mathrm{~Hz}, 2 \mathrm{H}, \mathrm{CH}_{2} \mathrm{NH}\right), 3.22(\mathrm{t}, J=4.6 \mathrm{~Hz}, 2 \mathrm{H}$, $\left.\mathrm{CH}_{2} \mathrm{NH}\right) 2.13\left(\mathrm{t}, J=7.4 \mathrm{~Hz}, 2 \mathrm{H}, \mathrm{CH}_{2} \mathrm{CO}\right), 1.87-1.84\left(\mathrm{~m}, 2 \mathrm{H}, \mathrm{CH}_{2} \mathrm{NCH}_{2} \mathrm{CH}_{2} \mathrm{C}\right) 1.38(\mathrm{~s}, 9 \mathrm{H}){ }^{13} \mathrm{C} \mathrm{NMR}$ $\left(100 \mathrm{MHz}, \mathrm{CDCl}_{3}\right) \delta(\mathrm{ppm}) 171.87,170.75,155.94,133.98,70.28,70.22,70.08,69.98,69.74,40.17$, 39.08, 37.12, 33.34, 28.27, 24.53. LC-MS: RT $=1.175 \min (\lambda=220 \mathrm{~nm}),[\mathrm{M}+\mathrm{H}]^{+}=458.7$ calculated exact mass: 457.24.

\section{Synthesis of $\mathbf{4}$}

Compound 3 (116.3 mg) was dissolved in $2 \mathrm{~mL}$ of DCM/TFA $(1: 1 \mathrm{v} / \mathrm{v})$. Reaction mixture was stirred for 2 hours at room temperature. Mixture was concentrated under reduced pressure to afford a clear oil without further purification (quantitative). $\mathrm{RT}=0.811 \min (\lambda=220 \mathrm{~nm}),[\mathrm{M}+\mathrm{H}]^{+}=358.1$ calculated exact mass: 357.19 .

General procedure for synthesis of FL1 and FL2

To a $3 \mathrm{~mL}$ DMF solution of compound 4 (80.0 mg) was added FITC (1.1 eq.) or Cy-5-NHS (1.1 eq.) in presence of triethylamine $(0.3 \mathrm{~mL})$. Reaction was stirred for 1 hour at room temperature. Mixture was then purified by preparative HPLC using a C18 column (Agilent Zorbax XDB-C18, 21.2 x 150 mm, 5 $\mu \mathrm{m})$ where mobile phase A was water $+0.1 \%$ formic acid and mobile phase B was $\mathrm{MeOH}+0.1 \%$ 
formic acid. The mobile phase gradient was: $0 \min -30 \% \mathrm{~B} ; 16 \min -95 \% \mathrm{~B} ; 20 \min -95 \% \mathrm{~B}$ followed by a column re-equilibration time of $4 \min$. FL1: $\mathrm{RT}=1.217 \min (\lambda=254 \mathrm{~nm}),[\mathrm{M}+\mathrm{H}]^{+}=747.2$ calculated exact mass: 746.23 . FL2: $\mathrm{RT}=1.262(\lambda=650 \mathrm{~nm}),[\mathrm{M}+\mathrm{H}]^{+}=823.7$ calculated exact mass: 822.48 .

General procedure for synthesis of FL1 or FL2 peptide conjugates

To 10 mg of peptide P3, G23, Scr or Cys was added a 1 mL DMF solution of FL1 (2 eq.) or FL2 (2 eq.) in presence of triethylamine $(10 \mu \mathrm{L})$. Reaction was stirred for 1 hour at room temperature. Mixture was then purified by preparative HPLC using a C18 column (Agilent Zorbax XDB-C18, 21.2 x 150 mm, 5 $\mu \mathrm{m})$ where mobile phase A was water $+0.1 \%$ formic acid and mobile phase $\mathrm{B}$ was $\mathrm{MeOH}+0.1 \%$ formic acid. The mobile phase gradient was: $0 \min -10 \% \mathrm{~B} ; 16 \min -95 \% \mathrm{~B} ; 20 \min -95 \% \mathrm{~B}$ followed by a column re-equilibration time of $4 \mathrm{~min}$. G23-FL1 HRMS m/z $[\mathrm{M}+3 \mathrm{H}]^{3+}$ calculated for $\mathrm{C}_{113} \mathrm{H}_{158} \mathrm{~N}_{25} \mathrm{O}_{29} \mathrm{~S}_{2}: 798.7106$ found: 798.71082. Scr-FL1 HRMS m/z $[\mathrm{M}+3 \mathrm{H}]^{3+}$ calculated for $\mathrm{C}_{113} \mathrm{H}_{158} \mathrm{~N}_{25} \mathrm{O}_{29} \mathrm{~S}_{2}: 798.7106$ found: 798.70975. P3-FL1 HRMS m/z $[\mathrm{M}+3 \mathrm{H}]^{3+}$ calculated for $\mathrm{C}_{126} \mathrm{H}_{179} \mathrm{~N}_{28} \mathrm{O}_{30} \mathrm{~S}_{2}: 877.1001$ found: 877.09934. Cys-FL1 HRMS m/z [M + 2H] $]^{2+}$ calculated for $\mathrm{C}_{40} \mathrm{H}_{45} \mathrm{~N}_{5} \mathrm{O}_{13} \mathrm{~S}_{2}$ : 434.6300 found: 434.63181. G23-FL2 HRMS m/z $[\mathrm{M}+3 \mathrm{H}]^{3+}$ calculated for $\mathrm{C}_{124} \mathrm{H}_{183} \mathrm{~N}_{26} \mathrm{O}_{25} \mathrm{~S}_{1}: 823.7929$ found: 823.79330. Scr-FL2 HRMS m/z $[\mathrm{M}+3 \mathrm{H}]^{3+}$ calculated for $\mathrm{C}_{124} \mathrm{H}_{183} \mathrm{~N}_{26} \mathrm{O}_{25} \mathrm{~S}_{1}: 823.7929$ found: 823.79325. P3-FL2 HRMS m/z $[\mathrm{M}+3 \mathrm{H}]^{3+}$ calculated for $\mathrm{C}_{137} \mathrm{H}_{204} \mathrm{~N}_{29} \mathrm{O}_{26} \mathrm{~S}_{1}$ : 902.1824 found: 902.18314 . Cys-FL2 HRMS m/z $[\mathrm{M}+2 \mathrm{H}]^{2+}$ calculated for $\mathrm{C}_{51} \mathrm{H}_{71} \mathrm{~N}_{6} \mathrm{O}_{9} \mathrm{~S}_{1}: 472.7574$ found: 472.75717.

\section{General procedure for ITC affinity measurement}

Calorimetry tests were performed using Microcal VP-ITC (Malvern Instruments Limited, Malvern, UK). Peptides or peptide conjugates were dissolved in Hank's balanced salt solution (HBSS) pH 6.5 to a concentration of $100 \mu \mathrm{M}$ and GM1 was dissolved in HBSS pH 6.5 to a concentration of $25 \mu \mathrm{M}$. Samples were heated to $25^{\circ} \mathrm{C}$ and degassed. Reference chamber was filled with buffer only, test chamber was filled with GM1 and injecting syringe was filled with peptide or peptide conjugate. Chamber temperature 
was set at $25^{\circ} \mathrm{C}, 25$ injections of $10 \mu \mathrm{L}$ were performed with an injection time of 20 seconds. Delay between each injection was 360 seconds and stir speed was $351 \mathrm{rpm}$. Reference power was set at 15 $\mu \mathrm{cal} / \mathrm{sec}$. The baseline of peptide dilution in buffer was subtracted from the results. Origin software was used to apply a simple interaction model of one binding site to calculate the association and dissociation constants, number of binding sites and enthalpy of binding, using the following equation:(33)

$$
\begin{gathered}
Q=\frac{n \mathrm{P}_{t} \Delta \mathrm{H} V_{0}}{2}\left[1+\frac{X_{t}}{n P_{t}}+\frac{1}{n \mathrm{~K}_{a} \mathrm{P}_{t}}-\sqrt{\left(1+\frac{X_{t}}{n \mathrm{P}_{t}}+\frac{1}{n a \mathrm{P}_{t}}\right)^{2}-\frac{4 X_{t}}{n \mathrm{P}_{t}}}\right] \\
\Delta Q_{(i)}=Q_{(i)}+\frac{d V_{(i)}}{V_{0}}\left[\frac{Q_{(i)}+Q_{(i-1)}}{2}\right]+Q_{(i-1)}
\end{gathered}
$$

where, $P_{t}$ is the concentration of protein in the active volume, $d V_{(i)}$ is the displaced volume, $V_{0}$ is the volume of the cell, $X_{t}$ is the concentration of the ligand in the active volume, $Q_{(i)}$ and $Q_{(i-l)}$ are the total heat evolved or absorbed for ith and $(i-1)$ th injections, respectively. Detailed derivation of the equations can be found in the VP ITC manual. Provide an initial estimate of $n, K_{a}$ and $\Delta \mathrm{H}$, which calculates $\Delta \mathrm{Q}_{(i)}$ for each injection. Then the program calculates the values of $n, K_{a}$, and $\Delta \mathrm{H}$ that provide the best fit to the calculated and experimental $\Delta \mathrm{Q}_{(i)}$. (33) Each experiment was repeated three times. Affinity of P3 for GM1 was analyzed by Microscale Thermophoresis (see supporting information).

\section{Cell culture}

T84 cells p20-30 (ATCC ${ }^{\circledR}$ CCL-248 ${ }^{\mathrm{TM}}$ ), derived from a lung metastasis of a human colon carcinoma, were maintained in a humidified $\mathrm{CO}_{2}(5 \%)$ incubator at $37^{\circ} \mathrm{C}$ in DMEM/F12 (1:1) (+L-Glutamine, $+15 \mathrm{mM}$ HEPES) supplemented with $10 \%$ heat-inactivated fetal bovine serum in the presence of penicillin and streptomycin. Caco-2 colon cells p30-40 (ATCC® HTB-37TM) were maintained in a humidified $\mathrm{CO}_{2}(5$ $\%$ ) incubator at $37^{\circ} \mathrm{C}$ in DMEM (+L-Glutamine, without sodium pyruvate, $+4.5 \mathrm{~g} / \mathrm{L}$ glucose) supplemented with $10 \%$ heat-inactivated fetal bovine serum in the presence of penicillin and 
streptomycin and non-essential amino acids. GM1 content of each cell line was evaluated by dot-blot in a semi-quantitative method (see supplementary information).

\section{General procedure for internalization by flow cytometry}

For internalization studies, $1 \times 10^{5}$ cells per well were plated in a 24 -well plate and incubated overnight. After incubation, adhesion and confluence of cells was verified. Cells were then rinsed twice with HBSS (with calcium, magnesium). Peptide conjugates were freshly dissolved in $500 \mu \mathrm{L}$ of pre-warmed Opti$\mathrm{MEM}^{\circledR}$ and added to the wells to a $10 \mu \mathrm{M}$ final concentration. After 90 minutes incubation, cells were rinsed 3 times with culture media, once with PBS, trypsinized and suspended in FACS buffer (95\% PBS, $5 \%$ FBS, $1.0 \mathrm{mM}$ EDTA). One minute before analysis, $250 \mu \mathrm{L}$ of trypan blue $4 \mathrm{mg} / \mathrm{mL}$ was added to the cells to quench surface fluorescence of membrane bound conjugates.(34). Cells were then analyzed on a FACS Calibur $^{\mathrm{TM}}$ flow cytometer (BD Biosciences, San Jose, CA). Fold change for each replicate (mean fluorescence intensity; FlowJo software vX.0.7, Ashland, OR) was calculated relatively to the control samples that did not receive any treatment. All experiments were realized in triplicate.

Internalization in presence of a GM1 supplement

GM1 can be given as a supplement as it associates with the cellular membrane and serves as a functional receptor, thereby improving GM1-mediated endocytosis of compounds. (35) Caco-2 cells were incubated overnight with $80 \mu \mathrm{g} / \mathrm{mL}$ of GM1 (Sigma Aldrich, St Louis, MO, USA) in serum-free media. The noncell associated GM1 was washed off with PBS. Cells were then treated as the general procedure for internalization studies with minor modifications: G23-FL1 and P3-FL1 concentrations were set at $1 \mu \mathrm{M}$ and CTB-FITC at $5 \mu \mathrm{g} / \mathrm{mL}$. All experiments were realized in triplicate.

Internalization in presence of a ganglioside synthesis inhibitor

PPMP (DL-threo-1-phenyl-2-palmitoylamino-3-morpholino-1-propanol) can be used to block the synthesis of gangliosides, including GM1 and GT1b. (36) Since PPMP is a glucosylceramide synthase inhibitor, the cellular membrane can also be affected in complex ways due to the turnover of gangliosides 
and ceramide accumulation.(37) Nevertheless, PPMP was reported to inhibit the uptake of CTB in multiple cell lines by downregulating GM1.(35) For PPMP inhibitor studies, cells were grown in cell culture medium and in the presence of $10 \mu \mathrm{M}$ PPMP for 3 days. $(35,36,38)$ They were then treated as internalization studies where G23-FL1 and P3-FL1 concentrations were set at $1 \mu \mathrm{M}$ and CTB-FITC at 5 $\mu \mathrm{g} / \mathrm{mL}$. All experiments were realized in triplicate.

\section{Permeability through cell monolayers}

Permeability studies were conducted as per standardized protocol with minor modifications (39). T84 cells were grown for 10 days on Transwell® (Corning, Corning, NY) permeable supports (polycarbonate membrane pore size $0.4 \mathrm{~mm}$, diameter $12 \mathrm{~mm}$ ) until TEER values reached $>1000 \Omega \mathrm{cm}^{2}$ at $37^{\circ} \mathrm{C}$ measured by Volt-Ohm meter (EMD Millipore Millicell-ERS, Ontario, Canada). Caco-2 cells were grown on Transwell® permeable supports (polycarbonate membrane pore size $0.4 \mathrm{~mm}$, diameter $12 \mathrm{~mm}$ ) for 2124 days until TEER values reached $>300 \Omega \mathrm{cm}^{2}$ at $37^{\circ} \mathrm{C}$. Peptide conjugates were added to the apical side at a concentration of $10 \mu \mathrm{M}$ in a $100 \mu \mathrm{L}$ volume of Opti-MEM® without phenol red. Basolateral side was filled with $600 \mu \mathrm{L}$ of Opti-MEM® without phenol red. Samples were taken $(200 \mu \mathrm{L})$ from the basolateral side at 1, 2 and 4 hours and replaced with fresh Opti-MEM® without phenol red. Fluorescence was measured in the basolateral side using a Safire microplate reader (Tecan, Seestrasse, Switzerland).

The apparent permeability coefficient $\left(P_{a p p}\right.$, unit: $\left.\mathrm{cm} / \mathrm{s}\right)$ is the amount of compound transported per time and surface unit. It is calculated according to the following equation:

$$
P a p p=\left(\frac{\mathrm{d} Q}{\mathrm{~d} t}\right) x\left(\frac{1}{A C o}\right)
$$

where $\mathrm{d} Q / \mathrm{d} t$ is the steady-state flux $(\mu \mathrm{mol} / \mathrm{s}), A$ is the surface area of the filter $\left(\mathrm{cm}^{2}\right)$ and $C_{0}$ is the initial concentration in the donor chamber $(\mu \mathrm{M})$.(39) Finally, TEER values were measured at the end of the experiment to validate the integrity of the membrane. All experiments were realized in triplicate.

General procedure for the synthesis of CTB-BSA(FITC) synthesis using dibenzocyclooctyne linkers: CTB$B S A(F I T C) V 1$ and $V 2$ 
In two separate Amicon filters (Amicon Ultracel $0.5 \mathrm{~mL}$ MWCO 30k), were added $10 \mu \mathrm{L}$ of BSA(FITC) $5 \mathrm{mg} / \mathrm{mL}$ to $490 \mu \mathrm{L}$ of $\mathrm{NaHCO}_{3}$ buffer $(\mathrm{pH}=8.5)$ and $50 \mu \mathrm{L}$ of $1 \mathrm{mg} / \mathrm{mL} \mathrm{CTB}$ to $450 \mu \mathrm{L}$ of $\mathrm{NaHCO}_{3}$ buffer $(\mathrm{pH}=8.5)$. The filters were centrifuged for 5 minutes at $12000 \mathrm{~g}$ and washed 4 times with $\mathrm{NaHCO}_{3}$ to exchange the buffers. The samples were then put upside down and centrifuged at $3300 \mathrm{~g}$ for 5 minutes to collect the proteins. $0.5 \mu \mathrm{L}$ of $40 \mathrm{mM}$ DBCO-NHS linker (Sigma-Aldrich, Oakville, ON, Canada) or DBCO-PEG 4 -NHS (Sigma-Aldrich, Oakville, ON, Canada) was added to the aliquot containing CTB and $0.2 \mu \mathrm{L}$ of $\mathrm{N}_{3}-\mathrm{PEG}_{3}$-NHS (40) $1 \mathrm{M}$ was added to aliquot containing BSA(FITC). The proteins were left to react for 30 minutes at room temperature. $10 \mu \mathrm{L}$ of Tris- $\mathrm{HCl} 1 \mathrm{M}$ was added in each aliquot and reaction was quenched for 30 minutes. The samples were then centrifuged 4 times with PBS in Amicon filters as described above to remove any unreacted linker. CTB-DBCO aliquot was added to the BSA(FITC)- $\mathrm{N}_{3}$ aliquot and reaction was left overnight at $4^{\circ} \mathrm{C}$. The next day, the resulting chimera protein was analyzed by non-denaturing SDS-PAGE (Bio-RAD $\left.{ }^{\mathrm{TM}}\right)$. CTB-BSA(FITC) conjugated with DBCO-PEG 4 -NHS was called CTB-BSA(FITC) V1, CTB-BSA(FITC) conjugated with DBCO-NHS was called CTB-BSA(FITC) V2.

Procedure for the synthesis of CTB-BSA(FITC) synthesis using GMBS: CTB-BSA(FITC) V3

In two separate Amicon filters (Amicon Ultracel $0.5 \mathrm{~mL}$ MWCO 30k), were added $10 \mu \mathrm{L}$ of BSA(FITC) $2 \mathrm{mg} / \mathrm{mL}$ to $490 \mu \mathrm{L}$ of PBS buffer $(\mathrm{pH}=7.4)$ and $15 \mu \mathrm{L}$ of CTB $1 \mathrm{mg} / \mathrm{mL}$ to $485 \mu \mathrm{L}$ of PBS buffer $(\mathrm{pH}=$ 7.4). The samples were centrifuged for 5 minutes at $12000 \mathrm{~g}$, and washed 4 times with PBS to exchange the buffers. The filters were then put upside down and centrifuged at $3300 \mathrm{~g}$ for 5 minutes to collect the proteins. $5 \mu \mathrm{L}$ of GMBS (100 mg/mL in DMSO) was added to the aliquot containing CTB. The reaction was left at room temperature for 60 minutes. CTB-GMBS was washed 4 times with PBS to remove unreacted GMBS. BSA(FITC) was then added to CTB-GMBS and reaction was left overnight at $4^{\circ} \mathrm{C}$. The next day, the resulting chimera protein CTB-BSA(FITC) V3 was analyzed by non-denaturing SDS-PAGE $\left(\right.$ Bio-RAD $\left.^{\mathrm{TM}}\right)$.

\section{Statistics}


Statistical analysis was performed using PRISM 6.01 software (GraphPad, La Jolla, CA, USA). To determine statistically significant differences in internalization and permeability studies, one-way analysis of variance (ANOVA) tests were performed where $\mathrm{p}$ values for multiple comparisons were adjusted using the Tukey correction. $\mathrm{p} \leq 0.05$ was considered significant; $* \mathrm{p}<0.05 ; * * \mathrm{p}<0.01 ; * * * \mathrm{p}<0.001$. 


\section{Results}

Synthesis of the peptide conjugates

Two peptides were selected for their GM1 binding affinity. G23, discovered by by phage display and also called Tet1, was reported to show affinity for GT1b(26) and GM1.(29) P3 was also identified by specific phage display using quartz crystal microbalance (QCM).(25) Finally, a scramble version of G23 was used to check the non-specific affinity of the conjugates for GM1.(29, 41) We selected a fluorophore (Cy5NHS or FITC) as a model drug, since it enables straightforward fluorescence detection and flow cytometry. The fluorophores (Cy5-NHS or FITC) were added on the amino group of a heterobifunctional linker based on a triethylene glycol unit (Scheme 1), frequently used in linker design due to its flexibility and good water-solubility.(42) The peptides (P3, G23, Scr) were condensed through their appended cysteine to the maleimide function of the linker to yield peptide conjugates FL1 or FL2 (Scheme 1). Serving as a negative control for the absence of peptide, a single cysteine was conjugated to the linker to prevent maleimide cross-reactivity with serum proteins in the culture medium. The peptide conjugates were purified by preparative HPLC and characterized by HPLC-MS/MS.

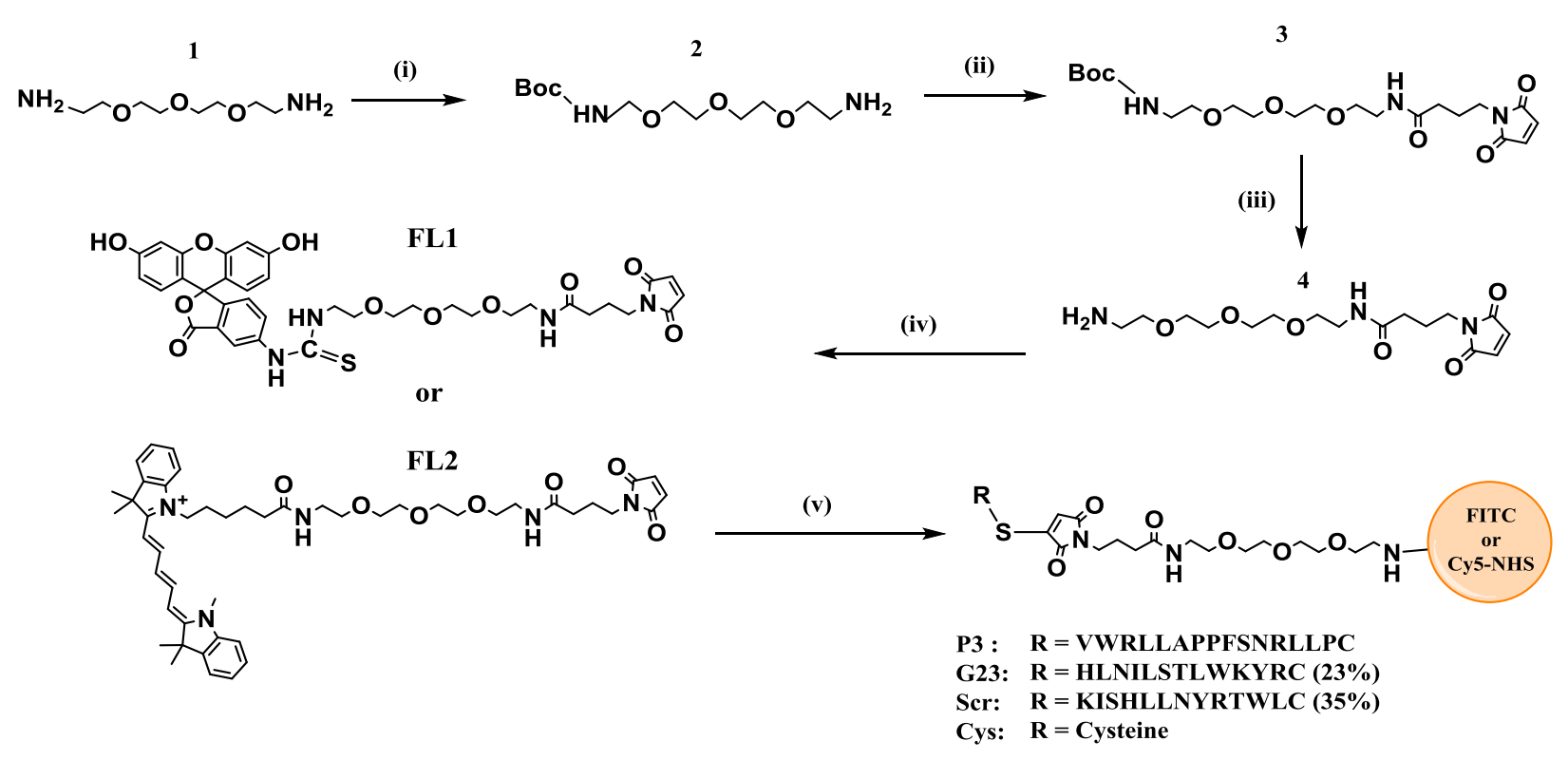


Scheme 1: Synthesis of peptide conjugates. Reagents and conditions: (i) $\mathrm{Boc}_{2} \mathrm{O}, \mathrm{DCM}, 5 \mathrm{~h}$ at $4{ }^{\circ} \mathrm{C}$ then $18 \mathrm{~h}$ at RT, DCM/ $\mathrm{H}_{2} \mathrm{O}$ extraction; (ii) GMBS, $\mathrm{N}$-methylmorpholine, DCM, room temperature, 16 hours, silica column DCM to EtOAc (iii) DCM/TFA (1:1), room temperature, 1 h; (iv) FITC or Cy5-NHS, Et ${ }_{3} \mathrm{~N}$, DMF, room temperature, $2 \mathrm{~h}$, preparative HPLC; (v) GM1 peptide, room temperature, $2 \mathrm{~h}$, preparative HPLC.

\section{Affinity evaluation of peptide conjugates}

Conjugating cell penetrating peptides with fluorescent probes such as FITC can alter the conformation and flexibility of the peptide which in turn can alter the affinity with its target.(43-45) Therefore, the affinity of peptide conjugates with GM1 was verified by isothermal titration calorimetry (ITC).(33, 46) As demonstrated in Table 1, the conjugation of FITC to G23 peptide (G23-FL1) did not alter the affinity for GM1 when compared to $\mathrm{G} 23$ alone $\left(\mathrm{K}_{\mathrm{d}}=418 \mathrm{nM}\right.$ and $455 \mathrm{nM}$, respectively). Unexpectedly, the scrambled G23 peptide exhibited a similar affinity for GM1 as the G23 peptide. However, once conjugated to a fluorescent probe (Scr-FL1), the affinity was reduced $\left(\mathrm{K}_{\mathrm{d}}=2597 \mathrm{nM}\right)$. These results suggest that conjugation does indeed impact the affinity, and that non-specific interactions are likely involved into GM1 binding for these peptides. Supporting this idea, we observed that, when G23 was conjugated to a model drug using a short propane spacer, the affinity towards GM1 was too low to be measured by ITC (data not shown). The short spacer was therefore discarded in subsequent studies. Since P3-FL1 exhibited solubility issues at the working peptide concentration $(100 \mu \mathrm{M})$, it was not possible to measure its affinity for GM1. We therefore used microscale thermophoresis (MST)(47) to measure a $\mathrm{K}_{\mathrm{d}}$ of $245 \mathrm{nM}$ of P3-FL1 for GM1 (Figure S1), confirming the affinity was preserved upon conjugation of P3 to FITC.

Table 1: Binding affinity of peptides $(100 \mu \mathrm{M})$ for the receptor GM1 $(25 \mu \mathrm{M})$ in pH 6.5 HBSS buffer measured by isothermal titration calorimetry (ITC) at $25^{\circ} \mathrm{C}$ or microscale thermophoresis (MST).

\begin{tabular}{ccccc}
\hline Compound & $\begin{array}{c}\text { Affinity constant } \mathrm{K}_{\mathrm{a}} \\
\left(\mathrm{M}^{-1}\right)\end{array}$ & $\begin{array}{c}\text { Dissociation constant } \\
\mathrm{K}_{\mathrm{d}}(\mathrm{nM})\end{array}$ & $\mathrm{N}($ sites $)$ & $\Delta \mathrm{H}(\mathrm{cal} / \mathrm{mol})$ \\
\hline G23 & $2.20 \mathrm{E6} \pm 4.74 \mathrm{E} 5$ & $455 \pm 98$ & $0.302 \pm 0.005$ & $-1.031 \mathrm{E} 4 \pm 378.7$ \\
Scrambled G23 & $2.31 \mathrm{E6} \pm 7.92 \mathrm{E} 5$ & $433 \pm 148$ & $0.073 \pm 0.007$ & $-2.970 \mathrm{E} 4 \pm 3933$ \\
G23-FL1 & $2.39 \mathrm{E} 6 \pm 4.66 \mathrm{E} 5$ & $418 \pm 82$ & $0.161 \pm 0.005$ & $-1.552 \mathrm{E} 4 \pm 671.1$ \\
\hline
\end{tabular}




\begin{tabular}{|c|c|c|c|c|}
\hline Scr-FL1 & $3.85 \mathrm{E} 5 \pm 1.08 \mathrm{E} 5$ & $2597 \pm 728$ & $0.050 \pm 0.024$ & $-8.477 \mathrm{E} 4 \pm 4.645 \mathrm{E} 4$ \\
\hline P3* & & $245 \pm 53$ & & \\
\hline
\end{tabular}

*Measured by miscroscale thermophoresis (MST). See Supporting Information and Figure S1.

\section{Internalization of peptide conjugates}

Since the peptide conjugates could not be discriminated according to their binding affinity, we compared their internalization into two different polarized cells lines (Caco-2 and T84) by flow cytometry (Figure 3). Caco-2 cells are routinely used to evaluate the in vitro permeability of drug candidates.(39) T84 is a human colon adenocarcinoma cell line reported to possess GM1 and where CTB transcytosis has been observed.(17) We compared the GM1 expression of Caco-2 and T84 cells using a semi-quantitative method and confirmed that T84 presented more GM1 than Caco-2 cells (Figure S2).(48, 49)

G23-FL1 and P3-FL1 were internalized significantly more in Caco-2 and T84 cells relative to controls Scr-FL1 and Cys-FL1 (Figure 1A and 1B). To examine the role of GM1 in the uptake, we fed the Caco-2 cells with a supplement of GM1, reported to improve the GM1 insertion in the plasma membrane and increase GM1-mediated uptake.(35) Surprisingly, this treatment did not improve the uptake of the peptide conjugates (Figure 1C), whereas it strongly increased the internalization of the whole cholera toxin subunit B (CTB-FITC) used as the positive control for GM1 binding.(35) The T84 cells, richer in GM1 than Caco-2 cells (Figure S2), were depleted by a pre-treatment with PPMP, which inhibits the synthesis of gangliosides and thus the membrane availability of GM1 and GT1b.(36) This treatment strongly reduced CTB-FITC uptake but not the internalization of the fluorescent peptide conjugates (Figure 1D). Both results, in Caco-2 and T84, suggest that the observed internalization of fluorescent peptide conjugates did not follow the same internalization pathway as CTB and was probably not only GM1dependent. Thus, we examined the internalization pathway of G23 peptide conjugates. In preliminary studies (Figure S3A and S3B), the endocytosis of G23-FL1 was partially inhibited by genistein in both cell lines and by methyl- $\beta$-cyclodextrin in Caco-2. This suggested the involvement of caveolae-mediated endocytosis.(50-52) 
A

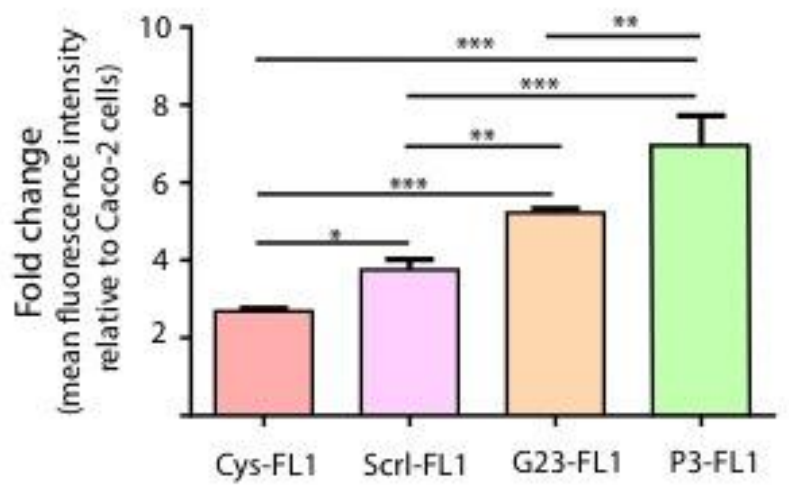

C

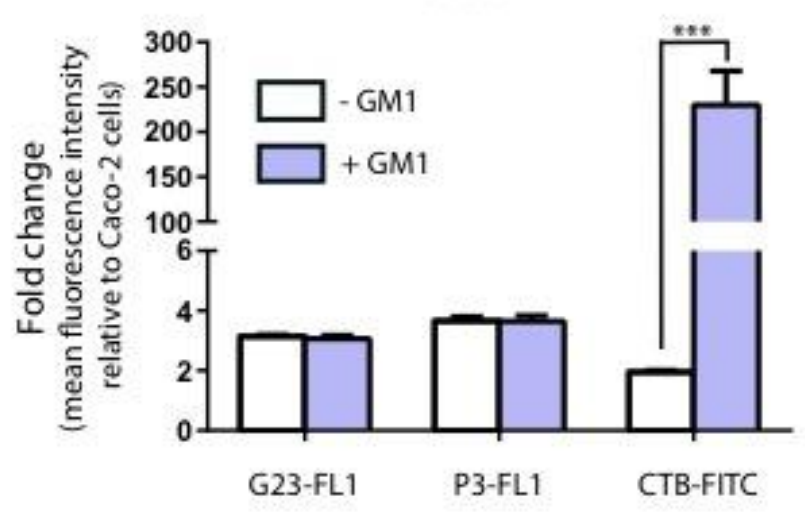

B

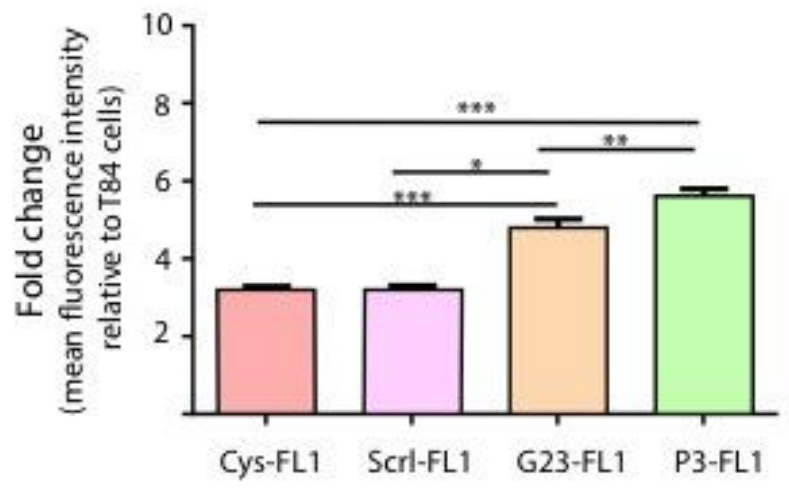

D

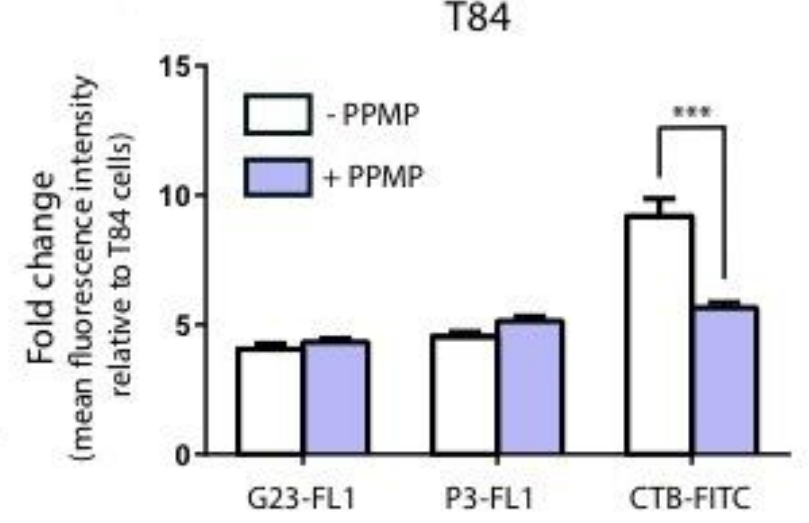

Figure 1: Internalization of fluorescent peptide conjugates. Cellular internalization of fluorescent peptide conjugates (G23-FL1, P3-FL1, Scr-FL1 and Cys-FL1) were analyzed by fluorescence activated cell sorting after quenching the external cell fluorescence by trypan blue. Mean fluorescence fold change $(\mathrm{n}=$ 3) of Caco-2 (A) and T84 (B) cells after 90 min incubation with fluorescent peptide conjugates as compared to the fluorescence of native cells $(n=3)$. C) Caco-2 cellular internalization of fluorescent peptide or cholera toxin B (FITC) after GM1 supplement treatment $(n=3)$. D) T84 cellular internalization of fluorescent peptide or cholera toxin B (FITC) after treatment with the ganglioside inhibitor PPMP $(\mathrm{n}=$ 3). Statistical analysis performed with one-way analysis of variance (ANOVA). *p $<0.05$; * $\mathrm{p}<0.01$; $* * * \mathrm{p}<0.001$

Permeability of peptide conjugates 
Even though cellular uptake did not appear to be mediated only by the GM1 receptor in our conditions, the conjugation to the peptide did increase uptake in both cell lines. Therefore, we monitored the permeability enhancement of the different peptide conjugates. In T84 cells, permeability of G23-FL1 was superior to Cys-FL1, representative of the drug alone (Figure 2B). However, there was no statistical difference between the scrambled peptide (Scr-FL1) and G23-FL1 in both cells lines. Also, peptide conjugates with Cy5 (-FL2) had overall permeability inferior to their -FL1 counterparts, highighting the

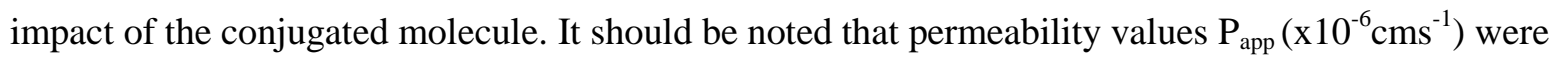
lower than 1 for all compounds in both cell lines and therefore were too low to translate to in vivo permeability.(53) Since our results confirmed the active role of GM1 in CTB internalization (Figure 1C), conjugation to the whole cholera toxin subunit B was further explored to increase intestinal permeability using GM1 pathway.

A

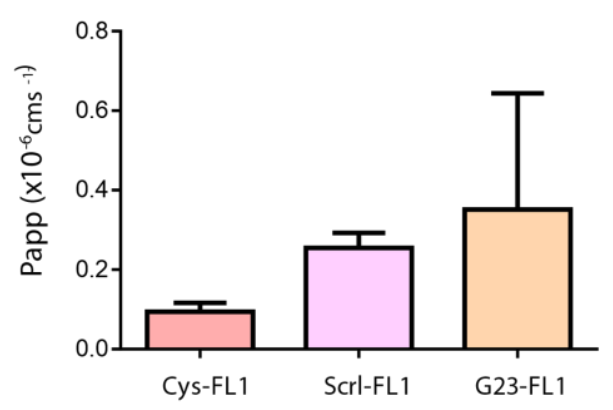

C

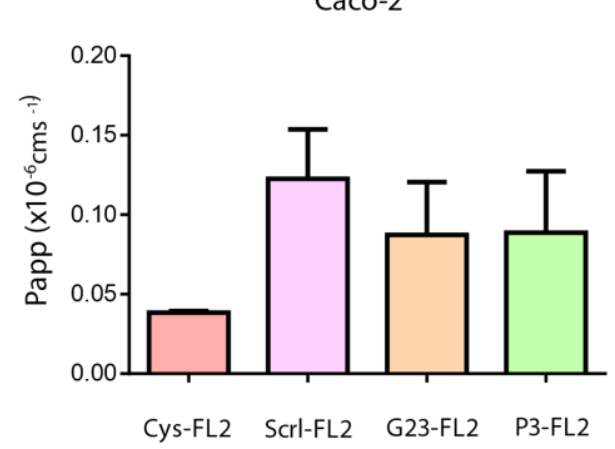

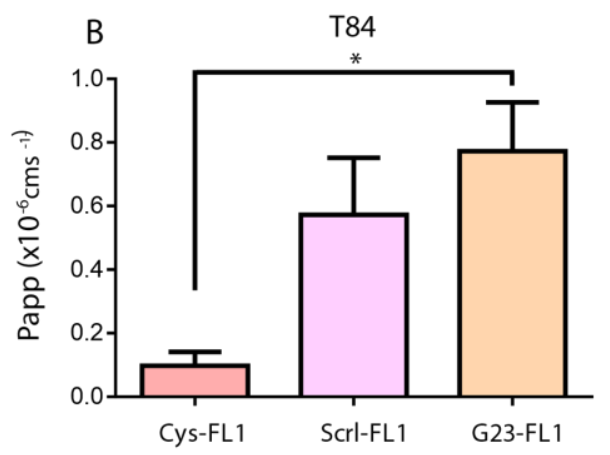

D

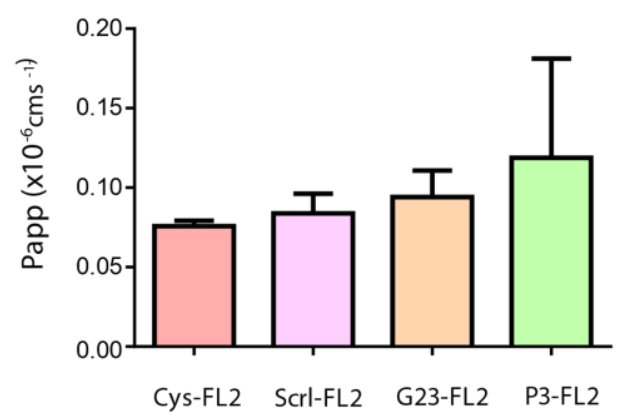

Figure 2: Permeability of fluorescent peptides conjugates. Permeability through cellular monolayers of Caco-2 (A, C) and T84 (B, D) was evaluated over 4h for peptides conjugated to FITC (A, B) and Cy5 (C, 
D). Statistical analysis performed with one-way analysis of variance (ANOVA). ${ }^{*} \mathrm{p}<0.05 ; * * \mathrm{p}<0.01$; $* * * \mathrm{p}<0.001$

\section{CTB-BSA fusion protein internalization and permeability}

As mentioned in the introduction, the cholera toxin subunit B (CTB) has already been used to prepare fusion protein for oral absorption.(19-22) As an alternative strategy, we investigated click chemistry to conjugate bovine serum albumin (BSA), used as a model biomacromolecule, to CTB (Figure 3A). Three linkers were compared for their conversion and bioconjugation yield. First, the commercial $\mathrm{N}-\gamma$ maleimidobutyryl-oxysuccinimide ester (GMBS) was used to link a cysteine of BSA-FITC to a lysine of CTB. Then, we functionalized CTB with dibenzocyclooctyne (DBCO) to react with azide-functionalized BSA, since this biorthogonal conjugation is copper free and produces high yields in biological media. Linkers V1 and V2 differ only by the tetraethylene glycol linker introduced between the proteins to balance the hydrophobicity of DBCO, which might hide in protein pockets and induce aggregation.(54) The reactions were compared using SDS-PAGE electrophoresis in non-denaturating conditions (Figure 3). These conditions allowed to visualize the pentameric CTB and its conjugated CTB-BSA(FITC). Using a longer and more hydrophilic tetraethylene glycol linker (V1) provided a stronger signal and superior yields as compared to other linkers (Figure 3), although all reactions still show the presence of unreacted BSA. The slight difference in migration of CTB-BSA(FITC) vs BSA(FITC) and the fragile nature of CTB prevented us from purification on AKTA-FPLC. CTB-BSA(FITC) V1 was therefore selected for internalization and permeability studies, similar to the peptide conjugates. 

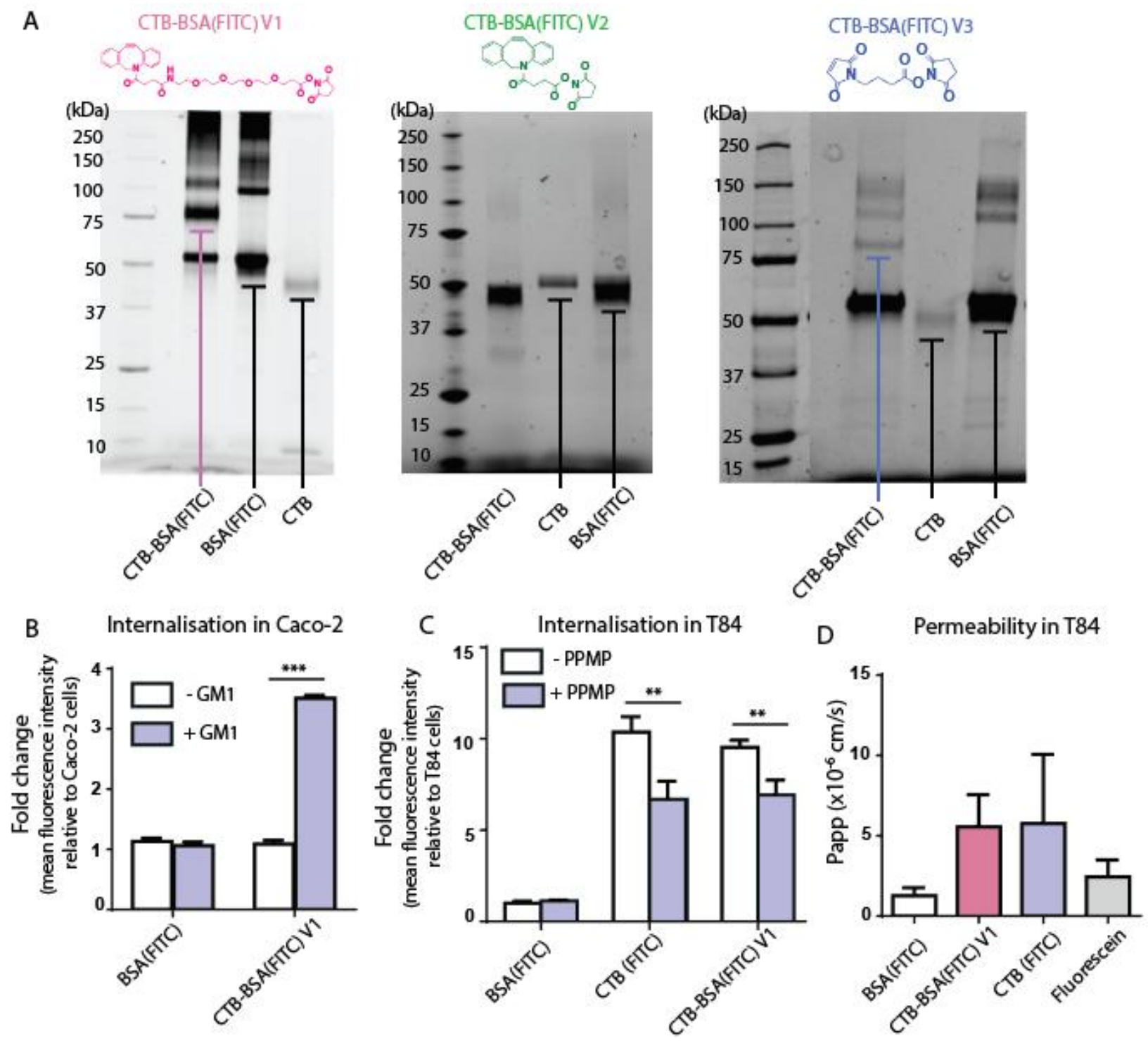

Figure 3: CTB-BSA fusion protein synthesis, internalization and permeability studies. A) Qualitative nondenaturing SDS-PAGE of CTB-BSA(FITC) fusion proteins using different linkers. B) Caco-2 cellular internalization of CTB-BSA(FITC) V1 before and after GM1 supplement treatment. C) T84 cellular internalization of CTB-BSA(FITC) V1 before and after treatment with the ganglioside inhibitor PPMP. D) Permeability of CTB-BSA(FITC) V1 in T84 cells. Statistical analysis performed with one-way analysis of variance (ANOVA). *p $<0.05 ; * * p<0.01 ; * * \mathrm{p}<0.001$ 
In Caco-2 cells, internalization of CTB-BSA(FITC) V1 was similar to BSA(FITC) but was strongly increased by a GM1 supplementation (Figure 3B), as observed with parent CTB (Figure 1C). This suggests that internalization is limited by the low amount of GM1 in Caco- 2 cells, in agreement with our GM1 assessment (Figure S2). In T84 cells, cell uptake was drastically improved thanks to CTB conjugation and significantly reduced when pretreated with ganglioside inhibitor PPMP (Figure 3C). These results confirmed the successful grafting of BSA-FITC to the CTB and strongly support the GM1mediated internalization into both cell lines. Finally, the permeability was assessed only in T84, since internalization in Caco-2 cells was not substantial. Permeability through a T84 cell layer was improved using CTB or CTB-BSA in a similar extend, although this was not statistically significant (Figure 3D). We ensured the integrity of the cell monolayer at the end of the experiment by TEER measurement.

\section{Discussion}

In this work, poorly permeable drug models were conjugated to GM1-binding peptides or to non-toxic Cholera Toxin subunit B (CTB) to improve their intestinal permeability. The novelty of this work relied on (i) the use of G23 instead of whole CTB for intestinal cell crossing, (ii) the use of G23-soluble conjugates instead of decorated nanoparticles reported for brain targeting and (iii) the optimization of linker click chemistry for bioconjugation with CTB.

The peptides (P3, G23) were selected from literature according to phage display results. $(25,29)$ To the best of our knowledge, this is the first time that affinity of G23 with GM1 was determined. The affinity constants obtained for P3 by MST $\left(\mathrm{K}_{\mathrm{D}}=254 \pm 53\right)$ were in the same range as previous literature $\left(\mathrm{K}_{\mathrm{D}}=\right.$ $1.2 \mu \mathrm{M}$ using quartz-crystal microbalance).(55) However, these values were much lower than the values reported for CTB for GM1 (5 pM to $1 \mathrm{nM}$, by Surface Plasmon Resonance and on-cell binding measurements).(16) In our conditions, the scramble peptide exhibited similar affinity than the parent G23 peptide (Table 1). In some conditions, the conjugation strongly impacted the affinity, since conjugated Scrl-FL1 reduced its affinity for GM1 (Table 1) and using Cy5 instead of FITC drastically decreased cell

permeability (Figure 2). This suggests a major role of non-specific interactions, likely related the physico- 
chemical properties of the residues (e.g. hydrophobicity, charge) rather than the precise sequence. G23 and its conjugates might present in a different spatial organization in solution, which could interfere with the GM1 binding mode. Similar impacts of the conjugation has been reported for several cell penetrating peptides (56) such as polyarginine,(57) Tat, $(58)$ penetratin $(58,59)$ and Angiopep, $(60)$ for which conjugation modified their physico-chemical properties and reduced their permeation enhancement properties. Finally, it is worth noting that the binding measurements were conducted in a solution of GM1. It is likely that GM1 was micellized in our conditions $(25 \mu \mathrm{M})$, since the critical micellar concentration (CMC) was reported to between $3.32 \mu \mathrm{M}$ and $29 \mu \mathrm{M}$ in aqueous media.(61, 62) In this case, the affinity value might be mainly due to the solubilization of peptides in the core of GM1 micelles, rather than specific interactions.

The second unexpected result was the internalization pathway of peptide conjugates. G23-FL1 and P3FL1 were weakly but significantly internalized in Caco-2 and T84 cells. However, this uptake was not mediated by GM1, since it was not impacted by a supplement of GM1 in Caco-2 (Figure 2C), nor by inhibition of ganglioside synthesis in T84 (Figure 2D). Consistent with this, the permeability of the peptide conjugates was only slightly increased in T84 as compared to the Cys-FL1, representative of the model drug alone (Figure 3B). Several hypotheses can be raised: (i) G23 and P3 might bind to GM1 but do not trigger internalization of the conjugates. Since these peptides have been discovered by phage display, they have not been selected on their ability to trigger endocytosis. Although transcytosis has been reported for G23-decorated nanoparticles through in vitro BBB models (hCMEC/D3 (30, 63) and bEnd.3 (31)), this was dependent on the nanoparticle composition.(64) Smaller, soluble bioconjugates might not trigger the same endocytosis pathway as nanoparticles. (ii) Conjugation to peptides might alter their internalization pathway, in the same way it impacted the affinity for GM1. This phenomenon was reported for the Angiopep peptide, which exploited different internalization mechanisms alone and when conjugated to a $\beta$-secretase inhibitor.(60) Our preliminary study indicated that caveolae-mediated endocytosis was involved in G23-FL1 internalization, since genistein decreased the cell uptake in both 
cell lines (Figure S3). This process was already reported for internalization of CTB in Caco-2 cells,(65) although several other routes have been reported for CTB in Caco-2, including caveolae-mediated, clathrin-mediated, noncaveloae/nonclathrin-dependent processes.(16) As for G23-decorated nanoparticles, their internalization was a saturated process on hCMEC/D3 cells (30) and involved receptor-mediated uptake on PC-12 (neurons),(27) but the endocytosis pathway was not investigated in Caco-2 cells. Interestingly, G23 ligand increased the uptake of nanoparticles into neurons (PC-12), but did not colocalize with CTB, suggesting a different internalization pathway.(64) Nevertheless, further studies, i.e. colocalization studies and/or the effect of dominant negative mutants of specific regulators of endocytosis are necessary to elucidate the endocytotic route of G23-peptide conjugates, since these chemical inhibitors lack specificity.(52)

Conversely to peptides, CTB-FITC exhibited a GM1-dependent pathway in Caco-2 and T84 cells (Figure $1 \mathrm{C}$ and 1D). It should be mentioned that in our experiments, Caco-2 did not express much GM1 (Figure S2) and required supplementation with external GM1 to trigger CTB endocytosis (Figure 1C). Our optimization study supported the idea that linkers containing ethylene glycol motifs enhanced the yield of the conjugated protein. The click chemistry requires only a 2-step reaction: (i) the grafting of a linker onto each protein, followed by (ii) the bioconjugation of functionalized macromolecules. As compared to the recombinant protein strategy, this method is versatile and can be easily translated to conjugate CTB with various macromolecules, such as heparin or siRNA. Furthermore, this strategy allows tuning the linker structure to be cleaved by $\mathrm{pH}$ or enzyme in a specific environment.(66) Nevertheless, the purification of the conjugated product, namely from the unreacted macromolecules, should be optimized in each case.

As expected the conjugation of CTB to BSA strongly improved the internalization of BSA in T84, and the process was still GM1-dependent (Figure 3C and 3D). Although the experiment showed a large variability, the $\mathrm{P}_{\text {app }}$ values reached 5.6 for T84 cells, which is higher than $\mathrm{P}_{\text {app }}$ of G23 conjugates (Figure 2). Lencer et al. have demonstrated that Cholera Toxin (CT) is endocytosed in an apical endosome also called "common endosome" (18). CT is then sorted according to the ceramide anchor of GM1 either to the 
endoplasmic reticulum $(\mathrm{ER})$ in a retrograde pathway, $(14,16)$ or to transcytotic vesicles in a distinct pathway.(18) In these studies, transcytosis of CTB through T84 cells was qualitatively observed (by gel electrophoresis), but was not quantified. We might hypothesize that transcytosis traffics a minor amount of CTB as compared to the portion processed through ER. It appears, however, that this process was sufficient to induce an immune response (24) or a pharmacological effect for insulin, myelin binding protein and amyloid-peptide B.(20-22) Further biodistribution studies after oral administration of fluorescent $\mathrm{CTB}$, could be envisaged to quantify the relevance of this mechanism and its impact in clinical translation.

\section{Conclusion}

In this study, we questioned the ability of GM1-binding peptides to improve the permeability of poor permeable drugs through a monolayer of intestinal cells. G23, P3 and Scramble peptide did improve the internalization into Caco-2 and T84 cells, but did not translate into improved permeability. Our results indicate that conjugation impacted the affinity for GM1 and suggest a strong contribution of non-specific interactions. In both cell lines, the peptides conjugates were internalized independent of the amount of GM1 in the cells, suggesting a different mechanism than CTB. On the other hand, conjugating cholera toxin subunit B (CTB) to a poorly permeable protein such as bovine serum albumin (BSA) provided promising improvements in internalization through a GM1-dependent pathway. Conjugating CTB to biomacromolecules via click chemistry seems a promising approach to improve cellular uptake of proteins such as vaccines, antibodies, heparins or siRNA in intestinal cells.

Acknowledgements: The authors acknowledge FRQNT, GRUM and RQRM for financial support, Martin Jutras for LC-MS/MS experiments, Dr. Badr, Dr. Najmanovich and Dr. Zylber for MST experiments, Sam Babity for English revision, and the summer interns Thien Sa Hoang, Félix-Antoine Le Sieur and Maxime Meloche. 
Supporting Information: MST measurements, GM1 quantification in T84 and Caco-2 cells, internalization studies using various inhibitors can be found in supplementary information. 


\section{References}

(1) Johnston, S. L. (2007) Biologic therapies: what and when? J. Clin. Pathol. 60, 8-17.

(2) Moroz, E., Matoori, S., and Leroux, J. C. (2016) Oral delivery of macromolecular drugs: Where we are after almost 100years of attempts. Adv. Drug Del. Rev. 101, 108-121.

(3) Rembratt, A., Graugaard-Jensen, C., Senderovitz, T., Norgaard, J. P., and Djurhuus, J. C. (2004) Pharmacokinetics and pharmacodynamics of desmopressin administered orally versus intravenously at daytime versus night-time in healthy men aged 55-70 years. Eur. J. Clin. Pharmacol. 60, 397-402.

(4) Emoto, C., Fukuda, T., Cox, S., Christians, U., and Vinks, A. A. (2013) Development of a Physiologically-Based Pharmacokinetic Model for Sirolimus: Predicting Bioavailability Based on Intestinal CYP3A Content. CPT Pharmacometrics Syst Pharmacol 2, e59.

(5) Calvert, M. J., McManus, R. J., and Freemantle, N. (2007) Management of type 2 diabetes with multiple oral hypoglycaemic agents or insulin in primary care: retrospective cohort study. Br. J. Gen. Pract. 57, 455-60.

(6) Nichols, G. A., Koo, Y. H., and Shah, S. N. (2007) Delay of insulin addition to oral combination therapy despite inadequate glycemic control: delay of insulin therapy. J. Gen. Intern. Med. 22, 453-8.

(7) Goodall, G., Sarpong, E. M., Hayes, C., and Valentine, W. J. (2009) The consequences of delaying insulin initiation in UK type 2 diabetes patients failing oral hyperglycaemic agents: a modelling study. BMC Endo. Dis. 9, 19.

(8) Kalra, S., Kalra, B., and Agrawal, N. (2010) Oral Insulin. Diabetology \& Metabolic Syndrome 2, 66.

(9) Malhaire, H., Gimel, J. C., Roger, E., Benoit, J. P., and Lagarce, F. (2016) How to design the surface of peptide-loaded nanoparticles for efficient oral bioavailability? Adv. Drug Del. Rev. 106, 320-336.

(10) Goldberg, M., and Gomez-Orellana, I. (2003) Challenges for the oral delivery of macromolecules. Nat. Rev. Drug Discov. 2, 289-95.

(11) Aungst, B. J. (2012) Absorption enhancers: applications and advances. AAPS J. 14, 10-8.

(12) Aroda, V. R., Rosenstock, J., Terauchi, Y., Jeppesen, O. L. E., Christiansen, E., Hertz, C. L., and Haluzik, M. (2018) Effect and Safety of Oral Semaglutide Monotherapy in Type 2 DiabetesPIONEER 1 Trial. Diabetes 67.

(13) Sandvig, K., and van Deurs, B. (2002) Membrane traffic exploited by protein toxins. Annu. Rev. Cell. Dev. Biol. 18, 1-24.

(14) Chinnapen, Daniel J. F., Hsieh, W.-T., te Welscher, Yvonne M., Saslowsky, David E., Kaoutzani, L., Brandsma, E., D'Auria, L., Park, H., Wagner, Jessica S., Drake, Kimberly R., Kang, M., Benjamin, T., Ullman, M. D., Costello, Catherine E., Kenworthy, Anne K., Baumgart, T., Massol, Ramiro H., and Lencer, Wayne I. (2012) Lipid Sorting by Ceramide Structure from Plasma Membrane to ER for the Cholera Toxin Receptor Ganglioside GM1. Dev. Cell 23, 573-586.

(15) Baldauf, K. J., Royal, J. M., Hamorsky, K. T., and Matoba, N. (2015) Cholera toxin B: one subunit with many pharmaceutical applications. Toxins (Basel) 7, 974-96.

(16) Chinnapen, D. J. F., Chinnapen, H., Saslowsky, D., and Lencer, W. I. (2006) Rafting with cholera toxin: endocytosis and trafficking from plasma membrane to ER. FEMS Microbiol. Lett. 266, 129137.

(17) Lencer, W. I., Moe, S., Rufo, P. A., and Madara, J. L. (1995) Transcytosis of cholera toxin subunits across model human intestinal epithelia. Proceedings of the National Academy of Sciences 92, 10094-10098. 
(18) Saslowsky, D. E., te Welscher, Y. M., Chinnapen, D. J.-F., Wagner, J. S., Wan, J., Kern, E., and Lencer, W. I. (2013) Ganglioside GM1-mediated Transcytosis of Cholera Toxin Bypasses the Retrograde Pathway and Depends on the Structure of the Ceramide Domain. J. Biol. Chem. 288, 25804-25809.

(19) Limaye, A., Koya, V., Samsam, M., and Daniell, H. (2006) Receptor-mediated oral delivery of a bioencapsulated green fluorescent protein expressed in transgenic chloroplasts into the mouse circulatory system. FASEB journal : official publication of the Federation of American Societies for Experimental Biology 20, 959-961.

(20) Ruhlman, T., Ahangari, R., Devine, A., Samsam, M., and Daniell, H. (2007) Expression of cholera toxin B-proinsulin fusion protein in lettuce and tobacco chloroplasts - oral administration protects against development of insulitis in non-obese diabetic mice. Plant Biotechnol. J. 5, 495510.

(21) Kohli, N., Westerveld, D. R., Ayache, A. C., Verma, A., Shil, P., Prasad, T., Zhu, P., Chan, S. L., Li, Q., and Daniell, H. (2014) Oral Delivery of Bioencapsulated Proteins Across Blood-Brain and Blood-Retinal Barriers. Mol. Ther. 22, 535-546.

(22) Li, S., Wei, Z., Chen, J., Chen, Y., Lv, Z., Yu, W., Meng, Q., and Jin, Y. (2014) Oral Administration of a Fusion Protein between the Cholera Toxin B Subunit and the 42-Amino Acid Isoform of Amyloid- $\beta$ Peptide Produced in Silkworm Pupae Protects against Alzheimer's Disease in Mice. PLOS ONE 9, e113585.

(23) Frey, A., Giannasca, K. T., Weltzin, R., Giannasca, P. J., Reggio, H., Lencer, W. I., and Neutra, M. R. (1996) Role of the glycocalyx in regulating access of microparticles to apical plasma membranes of intestinal epithelial cells: implications for microbial attachment and oral vaccine targeting. $J$. Exp. Med. 184, 1045-59.

(24) Harokopakis, E., Hajishengallis, G., and Michalek, S. M. (1998) Effectiveness of Liposomes Possessing Surface-Linked Recombinant B Subunit of Cholera Toxin as an Oral Antigen Delivery System. Infect. Immun. 66, 4299-4304.

(25) Matsubara, T., Ishikawa, D., Taki, T., Okahata, Y., and Sato, T. (1999) Selection of ganglioside GM1-binding peptides by using a phage library. FEBS Lett. 456, 253-256.

(26) Liu, J. K., Teng, Q., Garrity-Moses, M., Federici, T., Tanase, D., Imperiale, M. J., and Boulis, N. M. (2005) A novel peptide defined through phage display for therapeutic protein and vector neuronal targeting. Neurobiol. Dis. 19, 407-18.

(27) Park, I.-K., Lasiene, J., Chou, S.-H., Horner, P. J., and Pun, S. H. (2007) Neuron-specific delivery of nucleic acids mediated by Tet1-modified poly(ethylenimine). J. Gene Med. 9, 691-702.

(28) Kwon, E. J., Bergen, J. M., Park, I. K., and Pun, S. H. (2008) Peptide-modified vectors for nucleic acid delivery to neurons. J. Controlled Release 132, 230-235.

(29) Georgieva, J. V., Brinkhuis, R. P., Stojanov, K., Weijers, C. A., Zuilhof, H., Rutjes, F. P., Hoekstra, D., van Hest, J. C., and Zuhorn, I. S. (2012) Peptide-mediated blood-brain barrier transport of polymersomes. Angew. Chem. Int. Ed. Engl. 51, 8339-42.

(30) Georgieva, J. V., Brinkhuis, R. P., Stojanov, K., Weijers, C. A. G. M., Zuilhof, H., Rutjes, F. P. J. T., Hoekstra, D., van Hest, J. C. M., and Zuhorn, I. S. (2012) Peptide-Mediated Blood-Brain Barrier Transport of Polymersomes. Angew. Chem. Int. Ed. 51, 8339-8342.

(31) Su, C.-H., Tsai, C.-Y., Tomanek, B., Chen, W.-Y., and Cheng, F.-Y. (2016) Evaluation of blood-brain barrier-stealth nanocomposites for in situ glioblastoma theranostics applications. Nanoscale 8 , 7866-7870.

(32) Favre, A., Grugier, J., Brans, A., Joris, B., and Marchand-Brynaert, J. (2012) 6-Aminopenicillanic acid (6-APA) derivatives equipped with anchoring arms. Tetrahedron 68, 10818-10826. 
(33) Dutta, A. K., Rösgen, J., and Rajarathnam, K. (2015) Using Isothermal Titration Calorimetry to Determine Thermodynamic Parameters of Protein-Glycosaminoglycan Interactions. Methods in molecular biology (Clifton, N.J.) 1229, 315-324.

(34) Patino, T., Soriano, J., Barrios, L., Ibanez, E., and Nogues, C. (2015) Surface modification of microparticles causes differential uptake responses in normal and tumoral human breast epithelial cells. Sci Rep 5, 11371.

(35) Qi, R., Mullen, D. G., Baker, J. R., and Holl, M. M. (2010) The mechanism of polyplex internalization into cells: testing the GM1/caveolin-1 lipid raft mediated endocytosis pathway. Mol. Pharm. 7, 267-79.

(36) West, A. P., Dancho, B. A., and Mizel, S. B. (2005) Gangliosides Inhibit Flagellin Signaling in the Absence of an Effect on Flagellin Binding to Toll-like Receptor 5. J. Biol. Chem. 280, 9482-9488.

(41) Stojanov, K., Georgieva, J. V., Brinkhuis, R. P., van Hest, J. C., Rutjes, F. P., Dierckx, R. A., de Vries, E. F., and Zuhorn, I. S. (2012) In vivo biodistribution of prion- and GM1-targeted polymersomes following intravenous administration in mice. Mol. Pharm. 9, 1620-7.

(42) Wycisk, V., Achazi, K., Hirsch, O., Kuehne, C., Dernedde, J., Haag, R., and Licha, K. (2017) Heterobifunctional Dyes: Highly Fluorescent Linkers Based on Cyanine Dyes. ChemistryOpen 6, 437-446.

(43) Bechara, C., and Sagan, S. (2013) Cell-penetrating peptides: 20 years later, where do we stand? FEBS Lett. 587, 1693-702.

(44) Bertrand, J. R., Malvy, C., Auguste, T., Toth, G. K., Kiss-Ivankovits, O., Illyes, E., Hollosi, M., Bottka, S., and Laczko, I. (2009) Synthesis and studies on cell-penetrating peptides. Bioconjug. Chem. 20, 1307-14.

(45) Hedegaard, S. F., Derbas, M. S., Lind, T. K., Kasimova, M. R., Christensen, M. V., Michaelsen, M. H., Campbell, R. A., Jorgensen, L., Franzyk, H., Cardenas, M., and Nielsen, H. M. (2018) Fluorophore labeling of a cell-penetrating peptide significantly alters the mode and degree of biomembrane interaction. Sci Rep 8, 6327.

(46) Damian, L. (2013) Isothermal Titration Calorimetry for Studying Protein-Ligand Interactions, in Protein-Ligand Interactions: Methods and Applications (Williams, M. A., and Daviter, T., Eds.) pp 103-118, Humana Press, Totowa, NJ.

(47) Scheuermann, T. H., Padrick, S. B., Gardner, K. H., and Brautigam, C. A. (2016) On the acquisition and analysis of microscale thermophoresis data. Anal. Biochem. 496, 79-93.

(48) Wolf, A. A., Fujinaga, Y., and Lencer, W. I. (2002) Uncoupling of the cholera toxin-G(M1) ganglioside receptor complex from endocytosis, retrograde Golgi trafficking, and downstream signal transduction by depletion of membrane cholesterol. J. Biol. Chem. 277, 16249-56.

(49) Pang, H., Le, P. U., and Nabi, I. R. (2004) Ganglioside GM1 levels are a determinant of the extent of caveolae/raft-dependent endocytosis of cholera toxin to the Golgi apparatus. J. Cell Sci. 117, 1421-30.

(50) Torgersen, M. L., Skretting, G., van Deurs, B., and Sandvig, K. (2001) Internalization of cholera toxin by different endocytic mechanisms. J. Cell Sci. 114, 3737-47. 
(51) Walker, W. A., Tarannum, M., and Vivero-Escoto, J. L. (2016) Cellular Endocytosis and Trafficking of Cholera Toxin B-Modified Mesoporous Silica Nanoparticles. J Mater Chem B Mater Biol Med 4, 1254-62.

(52) Vercauteren, D., Vandenbroucke, R. E., Jones, A. T., Rejman, J., Demeester, J., De Smedt, S. C., Sanders, N. N., and Braeckmans, K. (2010) The use of inhibitors to study endocytic pathways of gene carriers: optimization and pitfalls. Mol. Ther. 18, 561-9.

(53) Volpe, D. A. (2010) Application of method suitability for drug permeability classification. AAPS J. $12,670-8$.

(54) Gong, H., Holcomb, I., Ooi, A., Wang, X., Majonis, D., Unger, M. A., and Ramakrishnan, R. (2016) Simple Method To Prepare Oligonucleotide-Conjugated Antibodies and Its Application in Multiplex Protein Detection in Single Cells. Bioconjug. Chem. 27, 217-25.

(55) Matsubara, T., lijima, K., Nakamura, M., Taki, T., Okahata, Y., and Sato, T. (2007) Specific binding of GM1-binding peptides to high-density GM1 in lipid membranes. Langmuir 23, 708-14.

(56) Munyendo, W. L. L., Lv, H., Benza-Ingoula, H., Baraza, L. D., and Zhou, J. (2012) Cell Penetrating Peptides in the Delivery of Biopharmaceuticals. Biomolecules 2, 187-202.

(57) Matsumoto, R., Okochi, M., Shimizu, K., Kanie, K., Kato, R., and Honda, H. (2015) Effects of the properties of short peptides conjugated with cell-penetrating peptides on their internalization into cells. Scientific Reports 5, 12884.

(58) Kristensen, M., de Groot, A. M., Berthelsen, J., Franzyk, H., Sijts, A., and Nielsen, H. M. (2015) Conjugation of Cell-Penetrating Peptides to Parathyroid Hormone Affects Its Structure, Potency, and Transepithelial Permeation. Bioconj. Chem. 26, 477-488.

(59) Hedegaard, S. F., Derbas, M. S., Lind, T. K., Kasimova, M. R., Christensen, M. V., Michaelsen, M. H., Campbell, R. A., Jorgensen, L., Franzyk, H., Cárdenas, M., and Nielsen, H. M. (2018) Fluorophore labeling of a cell-penetrating peptide significantly alters the mode and degree of biomembrane interaction. Scientific Reports 8, 6327.

(60) Kim, J. A., Casalini, T., Brambilla, D., and Leroux, J.-C. (2016) Presumed LRP1-targeting transport peptide delivers $\beta$-secretase inhibitor to neurons in vitro with limited efficiency. Sci. Rep. 6, 34297.

(61) Rauvala, H. (1979) Monomer-micelle transition of the ganglioside GM1 and the hydrolysis by Clostridium perfringens neuraminidase. Eur. J. Biochem. 97, 555-64.

(62) Basu, A., and Glew, R. H. (1985) Characterization of the activation of rat liver beta-glucosidase by sialosylgangliotetraosylceramide. J. Biol. Chem. 260, 13067-73.

(63) Stojanov, K., Georgieva, J. V., Brinkhuis, R. P., van Hest, J. C., Rutjes, F. P., Dierckx, R. A. J. O., de Vries, E. F. J., and Zuhorn, I. S. (2012) In Vivo Biodistribution of Prion- and GM1-Targeted Polymersomes following Intravenous Administration in Mice. Mol. Pharm. 9, 1620-1627.

(64) Wang, P., Zheng, X., Guo, Q., Yang, P., Pang, X., Qian, K., Lu, W., Zhang, Q., and Jiang, X. (2018) Systemic delivery of BACE1 siRNA through neuron-targeted nanocomplexes for treatment of Alzheimer's disease. J. Controlled Release 279, 220-233.

(65) Orlandi, P. A., and Fishman, P. H. (1998) Filipin-dependent inhibition of cholera toxin: evidence for toxin internalization and activation through caveolae-like domains. J. Cell Biol. 141, 905-15.

(66) Leriche, G., Chisholm, L., and Wagner, A. (2012) Cleavable linkers in chemical biology. Bioorg. Med. Chem. 20, 571-82. 